\title{
COMPOSITION OF SEED SOLUBLE CARBOHYDRATES AND ULTRASTRUCTURAL DIVERSITY OF TESTA IN LUPINS FROM THE MEDITERRANEAN REGION
}

\author{
AgNiesZKA I. PIOTROWICZ-CIEŚLAK \\ Department of Plant Physiology and Biotechnology \\ University of Warmia and Mazury \\ Oczapowskiego 1A, 10-718 Olsztyn, Poland \\ e-mail: acieslak@uwm.edu.pl
}

(Received: March 8, 2005. Accepted: June 8, 2005)

\begin{abstract}
This article present a comparison of soluble sugar levels in seeds of Lupinus atlanticus, Lupinus cosentinii, Lupinus palaestinus and Lupinus pilosus, Lupinus hispanicus subsp. hispanicus and Lupinus luteus of Juno variety. Considering that sugars are accumulated in embryos, only the embryonic tissues were used for biochemical analyses. Additionally, the share of testa and embryo in seed tissues was evaluated. The seed-coat thickness was measured using scanning electron microscopy. The seed coat had the largest share in seeds of Lupinus pilosus and Lupinus palaestinus, and the least share in seeds of Lupinus hispanicus subsp. hispanicus and Lupinus luteus of Juno variety. In the seed of Lupinus pilosus the thickness of the seed coat was $1100 \mu \mathrm{m}$, while in Lupinus luteus it was $300 \mu \mathrm{m}$. The analysed Lupinus seeds accumulated from $73 \mathrm{mg} / \mathrm{g} \mathrm{d.m}$. (dry matter of seed embryo) to $155 \mathrm{mg}$ of soluble sugars/g d.m. The highest quantity of oligosaccharides of the raffinose series was found in seeds of Lupinus luteus, while the lowest amount in seed of Lupinus palaestinus. Galactosyl cyclitols appeared in largest amount in seeds of Lupinus palaestinus and Lupinus pilosus, appropriately 41.93 and $33.75 \mathrm{mg} / \mathrm{g} \mathrm{dm}$. The lowest amount of galactosyl cyclitols appeared in Lupinus atlanticus, Lupinus cosentinii and Lupinus hispanicus.
\end{abstract}

KEY WORDS: Lupinus seeds, seed coat, cyclitols, galactosyl cyclitols, raffinose family oligosaccharides, gas chromatography, scanning electron microscopy.

\section{INTRODUCTION}

Lupinus L. (Fabaceae) is a large and diverse genus comprising 200-500 annual and perennial herbaceous species, as well as a few soft-woody shrubs and small trees (Turner 1995) which occur in a wide range of ecogeographical conditions in both the New and the Old World. Only 12-13 species are native to the Mediterranean region and Africa, with some populations extending to highlands of East African tropical areas (Gladstones 1998). Old World lupins are all annual, herbaceous, and predominantly autogamous. Their fruits and seeds are generally large, and their leaves are always digitate. Two distinct groups are recognized primarily on the basis of the seed coat texture: the smooth-seeded and the rough-seeded species (Heyn and Herrnstadt 1977). The smooth-seeded group comprises five species usually treated as members of four sections, Albi, Micranthi, Angustifoli, and Lutei (Gladstones 1998). This group is generally typified by L. pilosus Murr. and often designated at sectional rank. The rough-seeded species are mainly di- stributed in North Africa and in the eastern part of the Mediterranean region.

Apart from the characteristic structure of seed coat, the seeds of lupin are distinguished by presence of oligosaccharides of the raffinose family (RFO). Raffinose, stachyose and verbascose are members of this group. For years these compounds were considered undesirable in human diet. However, nowadays they undergo a reappraisal. They are accumulated in the process of seed maturation and are used during germination. Recent development in nutritional sciences are changing the opinion on their actual role (Alles et al. 1999). The digestive tract of humans and monogastric animals lacks the enzymes breaking down $\alpha(1 \rightarrow 6)$-galactosyl linkage. It is hydrolysed however, in the large intestine by bacterial galactosidase. The effect (Tomomatsu 1994; Hamilton-Miller 2000) of discomfort after consumption of $\alpha$-D-galactosides is caused by enterobacteriae of the digestive tract, which produce hydrogen, methane and carbon dioxide. RFO supplied in larger quantities with food stimulates the bacterial flora of the digesti- 

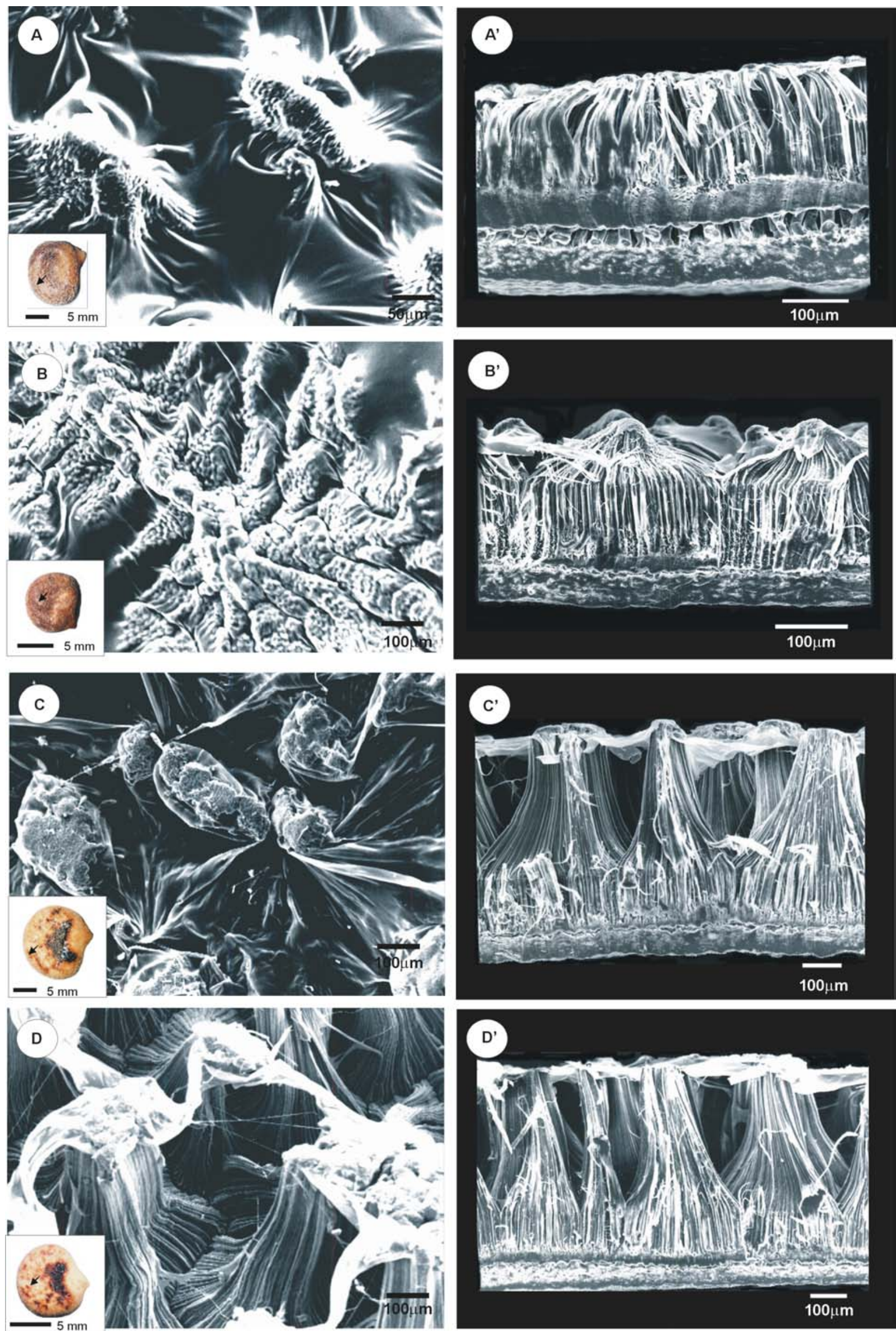

Fig. 1. Scanning electron micrographs of selected seeds of Lupinus. Each figure is divided into an A, B, C, D panel coat surface of seed (showing the entire seed) and A', B', C', D' panel transverse section coat of seeds.

A, A' - Lupinus atlanticus B, B' - Lupinus cosentinii, C, C' - Lupinus palaestinus, D, D' - Lupinus pilosus 

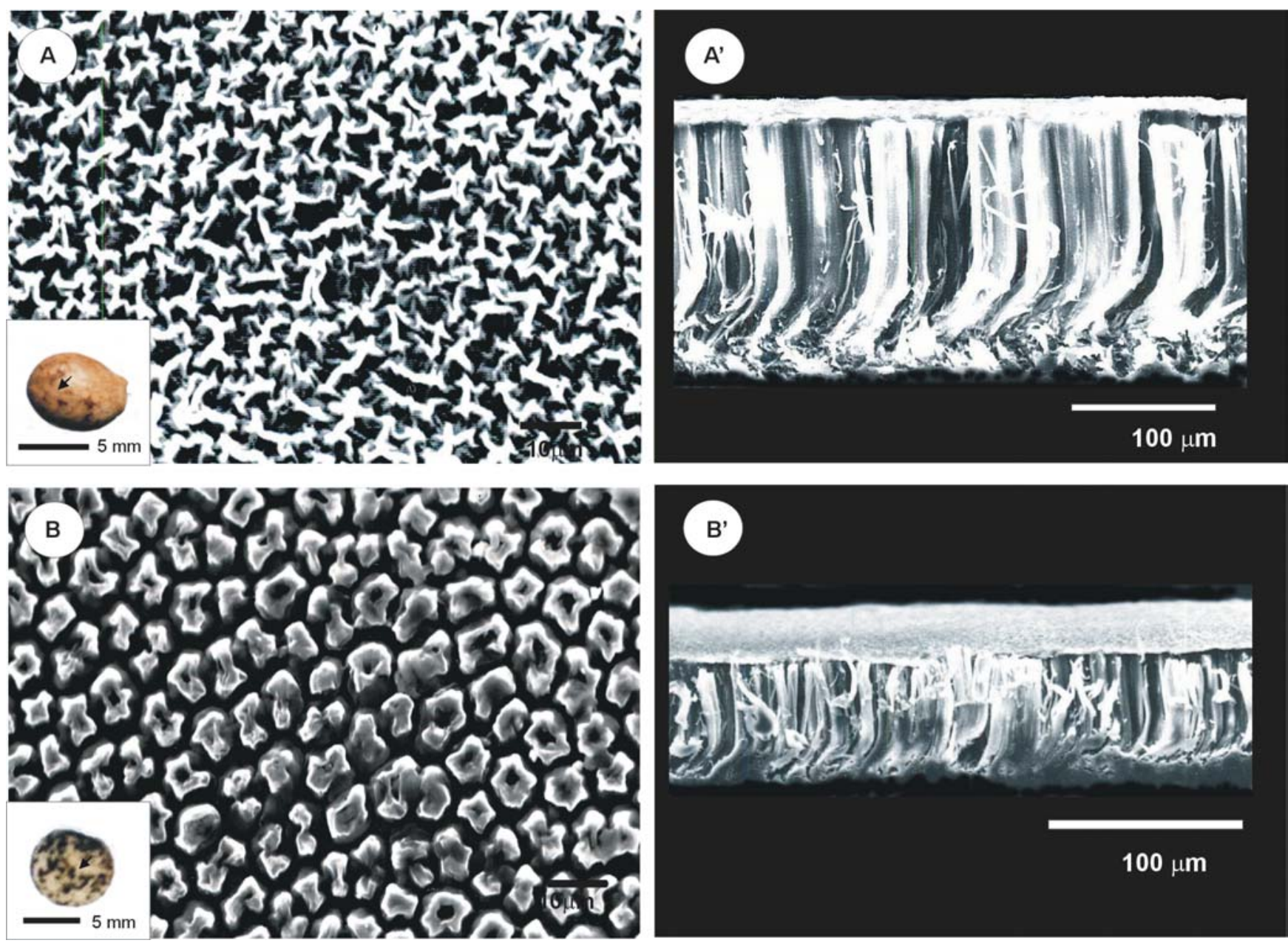

Fig. 2. Scanning electron micrographs of selected seeds of Lupinus. Each figure is divided into an A, B panel coat surface of seed (which showing the entire seed) and A', B' panel ransverse section coat of seeds.

A, A' - Lupinus hispanicus subsp. hispanicus B, B' - Lupinus luteus cv. Juno

ve tract. As a result, bifidobacteria dominate the intestinal microflora. They appear beneficial for the organism through stimulating the immune system. Consumption of $\alpha$-D-galactosides diminishes the risk of large-intestine tumours (Gibson and Roberfroid 1995).

Lupins are especially rich in oligosaccharides of the raffinose series (Piotrowicz-Cieślak et al. 1999). These compounds appear in the axes in quantities two or three times bigger than in cotyledons (Górecki et al. 1997). In seed coats these oligosaccharides do not appear. It seems that in terms of the contents of RFO a thin seed coat and a big embryo would be most satisfactory. This paper's objective was to compare the carbohydrate composition and the share of seed testa in seeds of wild growing lupin and cultivated yellow lupin of Juno variety.

\section{MATERIAL AND METHODS}

\section{MATERIAL}

Seeds of six lupins from Mediterranean species were used in the experiments: four species: Lupinus atlanticus, Lupinus cosentinii, Lupinus palaestinus and Lupinus pilosus were rough-seed species, and Lupinus hispanicus subsp. hispanicus and Lupinus luteus cv. Juno were smooth-seeded (Table 1).
METHODS

Scanning electron microscopy

For observation in the scanning electron microscope (SEM) the seeds were coated with gold using a JEOL JFC

TABLE 1. List and origin of species of seeds from genus Lupinus used for investigations.

No. Species Section Main areas of occurrence

\begin{tabular}{|c|c|c|c|}
\hline \multicolumn{4}{|c|}{ The Mediterranean rough-seeded species } \\
\hline 1 & Lupinus pilosus Murr. & Pilosus & Turkey \\
\hline 2 & Lupinus palaestinus Boiss. & Pilosus & Israel \\
\hline 3 & Lupinus atlanticus Glads. & Atlanticus & Marocco \\
\hline 4 & Lupinus cosentinii Guss. & Atlanticus & Spain \\
\hline \multicolumn{4}{|c|}{ The Mediterranean smooth-seeded species } \\
\hline 5 & $\begin{array}{l}\text { Lupinus hispanicus } \\
\text { Boiss. et Reut. } \\
\text { subsp. hispanicus }\end{array}$ & Luteus & Spain \\
\hline 6 & $\begin{array}{l}\text { Lupinus } \\
\quad \text { luteus L. cv. Juno }\end{array}$ & Luteus & Poland \\
\hline
\end{tabular}


TABLE 2. The morphological characteristic of Lupinus genus seeds (values are mean \pm SD of the mean for fifteen replicate samples).

\begin{tabular}{lccc}
\hline \multirow{2}{*}{$\begin{array}{l}\text { Species genus of seeds } \\
\text { Lupinus atlanticus }\end{array}$} & $\begin{array}{c}\text { Weight } \\
{\left[\mathrm{mg} \times \mathrm{seeds}^{-1}\right]}\end{array}$ & \multicolumn{2}{c}{ Anatomical part of seeds [\%] } \\
\cline { 3 - 4 } Lupinus cosentinii & $207.4 \pm 6.5$ & $66.8 \pm 2.7$ & axis \\
Lupinus palaestinus & $213.9 \pm 8.3$ & $69.4 \pm 4.8$ & $2.7 \pm 0.4$ \\
Lupinus pilosus & $592.4 \pm 14.8$ & $66.5 \pm 3.4$ & $5.2 \pm 0.3$ \\
Lupinus hispanicus subsp. hispanicus & $548.7 \pm 15.2$ & $64.4 \pm 2.4$ & $1.3 \pm 0.2$ \\
Lupinus luteus cv. Juno & $136.7 \pm 6.7$ & $72.0 \pm 4.7$ & $1.8 \pm 0.2$ \\
\hline
\end{tabular}

1200 ion coater and observed in a JEOL JSM-5310LV scanning electron microscope under a $20 \mathrm{kV}$.

\section{Soluble sugars}

Cyclitols, galactosyl cyclitols and soluble sugars content were analyzed according to Piotrowicz-Cieślak et al. (2003). Dry and fresh tissue mass were also examined. 30 $\mathrm{mg}$ of dry milled embryo tissue were homogenized in ethanol: water, 1:1 (v/v) containing $100 \mu \mathrm{g}$ phenyl- $\alpha-\mathrm{D}$-glucose as internal standard (Horbowicz and Obendorf 1994). The homogenate and the rinse were combined in a $1.5-\mathrm{ml} \mathrm{mi-}$ crofuge tube, heated at $75^{\circ} \mathrm{C}$. for $30 \mathrm{~min}$ to inactivate endogenous enzymes and centrifuged in a centrifuge MPW-365 (Poland) at $15000 \mathrm{~g}$ for $20 \mathrm{~min}$. The supernatant was passed through a 10000 MW cut-off filter (Lida, Kenosha, USA). Aliquots of $0.5 \mathrm{ml}$ filtrate were transferred to silylation vials and evaporated to dryness under a nitrogen stream. Residues were kept overnight in a desiccator, over phosphorus pentoxide. Dry residues were derived with 300 $\mu 1$ of silylation mixture (trimethylsilylimidazole: pyridyne, $1: 1, \mathrm{v} / \mathrm{v}$ ) in silylation vials (Supelco) at $70^{\circ} \mathrm{C}$ for $30 \mathrm{~min}$ and then cooled at room temperature. One $\mu \mathrm{l}$ of dried soluble carbohydrates was injected into a split-mode injector of a Shimadzu GC-14A gas chromatograf equipped with flame ionization detector and Shimadzu C-R6A integrator. Soluble carbohydrate were analysed on a DB-1 capillary column (15 m lengh, $0.25 \mathrm{~mm}$ ID, $0.25 \mu \mathrm{m}$ film thickness, Varian) operated with a programmed initial temperature of $150^{\circ} \mathrm{C}$, adjusted to $200^{\circ} \mathrm{C}$ at $3^{\circ} \mathrm{C} / \mathrm{min}$, adjusted $325^{\circ} \mathrm{C}$ at $7^{\circ} \mathrm{C} / \mathrm{min}$, and held $325^{\circ} \mathrm{C}$ for $40 \mathrm{~min}$, the injector port was at $335^{\circ} \mathrm{C}$ and the detector at $350^{\circ} \mathrm{C}$. The carrier gas was helium at $3 \mathrm{ml} / \mathrm{min}$, split 1:50 and the detector gas were hydrogen at $30 \mathrm{ml} / \mathrm{min}$ and air at $300 \mathrm{ml} / \mathrm{min}$. Soluble carbohydrates were identified with intermediate standards as available and calculated from the ratios of area of peaks for each known carbohydrate to the area of peak for the internal standards.

\section{RESULTS}

\section{Morphological analysis}

The analysed seeds of Lupinus were distinguished by considerable morphological variation. It was related to seed colour, shape and size. The biggest were seeds of Lupinus palaestinus $(\varnothing 14 \mathrm{~mm})$ and L. pilosus $(\varnothing 12 \mathrm{~mm})$, the smallest were L. hispanicus and L. luteus (Figs 1 and 2). The same regularities were observed in the mass of the seeds, which was highest in L. palaestinus and L. pilosus, while the lowest in L. hispanicus and L. luteus (Table 2). The share of the seed coat in various anatomical parts of the seeds ranged from 33.8 to $23.1 \%$, for L. pilosus and $L$. hispanicus subsp. hispanicus, respectively. The square shaped seeds (L. palaestinus and L. pilosus) had the highest share of seed coats, while the ball shaped seeds had the smallest one. Electron microscopy showed a high variety of surface relief and seed coat thickness. The thickness ranged from $100 \mu \mathrm{m}$ to $1100 \mu \mathrm{m}$, in L. luteus and L. pilosus, respectively. The seeds with the thickest coats featured the biggest epidermal sclereids. Subepidermal sclereids were biggest in Lupinus atlanticus (ca. $30 \mu \mathrm{m}$ ). In other lupin species the size of subepidermal sclereids varied from 1 to $10 \mu \mathrm{m}$. The seeds having thin coats $-L$. hispanicus and $L$. luteus - had a thick and continuous cuticle. The thickest cuticle appeared in the seeds of L. luteus $(30 \mu \mathrm{m})$. The seeds of L. atlanticus, cosentinii, palaestinus and pilosus had thin and shattered cuticles (Figs 1 and 2).

\section{Soluble sugar composition of lupin seeds}

The research comparing Lupinus atlanticus, cosentinii, palaestinus, pilosus, hispanicus and luteus, showed a high variation in quantity and quality of soluble carbohydrates (Table 3). The seeds accumulated monosaccharides, sucrose, cyclitols, galactosyl cyclitols and oligosaccharides of the raffinose series. The content of soluble sugars in the analysed seeds of all varieties averaged $114 \mathrm{mg} / \mathrm{g}$ dry matter of embryo (d.m.). The highest content of soluble sugars was found in L. pilosus (155.51 mg/g d.m.), the lowest in L. cosentinii (73 mg/g d.m.). The seeds of L. hispanicus and L. luteus accumulated more than $100 \mathrm{mg}$ of soluble carbohydrates per $1 \mathrm{~g}$ of embryo dry matter (Table 3). A not much lower level of soluble sugars was found in $L$. palaestinus and L. atlanticus, and it was 99.92 and 96.24 $\mathrm{mg} / \mathrm{g}$ d.m., respectively. Regardless of the quantity of synthesised soluble sugars, the RFO contributed substantially (63\%) to this group of compounds. They included raffinose, stachyose and verbascose. The share of the oligosaccharides of the raffinose series ranged from 45 to $76 \%$ in total soluble sugars. Among these oligosaccharides stachyose dominated. It appeared in the highest amount in the seeds of Lupinus luteus of Juno variety $(59.2 \mathrm{mg} / \mathrm{g} \mathrm{d.m}$.), and in the lowest amount in the seeds of Lupinus palaestinus (21.82 mg/g d.m.). From the remaining oligosaccharides of the raffinose series, verbascose reached higher concentration than raffinose. The highest level of raffinose appeared in L. hispanicus, the lowest in L. cosentinii. The highest concentration of verbascose was found in L. luteus (Table 3) and the lowest in L. atlanticus.

Apart from the high level of RFO, the seeds of lupin contained considerable amounts of galactosyl cyclitols, represented by the products of myo-inositol, pinitol A and B. The Lupinus seeds contained from 5 to 8 galactosyl cyclitols. In all the analysed seeds there was galactinol, digalac- 
TABLE 3. Composition of soluble carbohydrates (mg per g dry matter) in lupin seeds from the Mediterranean Sea (values are mean \pm SD of the mean for four replicate samples).

\begin{tabular}{|c|c|c|c|c|c|c|}
\hline \multirow{2}{*}{$\begin{array}{l}\text { Soluble carbohydrates } \\
{[\mathrm{mg} / \mathrm{g}]}\end{array}$} & \multicolumn{4}{|c|}{ Rough-seeded } & \multicolumn{2}{|c|}{ Smooth-seeded } \\
\hline & L. atlanticus & L. cosentinii & L. palaestinus & L. pilosus & $\begin{array}{l}\text { L. hispanicus } \\
\text { subsp. hispanicus }\end{array}$ & $\begin{array}{l}\text { L. luteus } \\
\text { cv. Juno }\end{array}$ \\
\hline \multicolumn{7}{|c|}{ Monosaccharides and sucrose } \\
\hline $\begin{array}{l}\text { fructose } \\
\text { glucose } \\
\text { galactose } \\
\text { sucrose }\end{array}$ & $\begin{array}{c}1.99 \pm 0.02 \\
0.15 \pm 0.000 \\
0 \\
18.86 \pm 1.99\end{array}$ & $\begin{array}{c}1.78 \pm 0.06 \\
0.11 \pm 0.01 \\
0 \\
19.04 \pm 1.64\end{array}$ & $\begin{array}{l}2.80 \pm 0.22 \\
0.11 \pm 0.06 \\
0.08 \pm 0.08 \\
15.6 \pm 1.23\end{array}$ & $\begin{array}{c}6.26 \pm 0.17 \\
0.10 \pm 0.01 \\
0.12 \pm 0.12 \\
32.65 \pm 1.56\end{array}$ & $\begin{array}{c}1.33 \pm 0.22 \\
0.07 \pm 0.01 \\
0 \\
15.54 \pm 1.35\end{array}$ & $\begin{array}{l}1.33 \pm 0.31 \\
0.89 \pm 0.16 \\
0.85 \pm 0.07 \\
27.9 \pm 1.47\end{array}$ \\
\hline \multicolumn{7}{|c|}{ Cyclitols } \\
\hline $\begin{array}{l}\text { D-pinitol } \\
\text { myo-inositol } \\
\text { D-chiro-inositol }\end{array}$ & $\begin{array}{l}0.34 \pm 0.05 \\
0.74 \pm 0.09 \\
0.12 \pm 0.02\end{array}$ & $\begin{array}{l}0.33 \pm 0.01 \\
0.70 \pm 0.08 \\
0.11 \pm 0.01\end{array}$ & $\begin{array}{l}0.14 \pm 0.02 \\
0.25 \pm 0.08 \\
0.11 \pm 0.04\end{array}$ & $\begin{array}{l}0.08 \pm 0.02 \\
1.24 \pm 0.34 \\
0.23 \pm 0.04\end{array}$ & $\begin{array}{l}2.95 \pm 0.44 \\
1.19 \pm 0.09 \\
0.23 \pm 0.03\end{array}$ & $\begin{array}{l}0.66 \pm 0.07 \\
0.18 \pm 0.01 \\
2.07 \pm 1.47\end{array}$ \\
\hline $\begin{array}{l}\text { myo-inositol serie: } \\
\text { galactinol } \\
\text { digalacto-myo-inositol }\end{array}$ & $\begin{array}{l}0.98 \pm 0.11 \\
0.23 \pm 0.04\end{array}$ & $\begin{array}{l}1.02 \pm 0.14 \\
0.22 \pm 0.03\end{array}$ & $\begin{array}{l}0.17 \pm 0.02 \\
1.96 \pm 0.03\end{array}$ & $\begin{array}{l}0.73 \pm 0.03 \\
4.54 \pm 0.67\end{array}$ & $\begin{array}{l}1.84 \pm 0.17 \\
0.74 \pm 0.08\end{array}$ & $\begin{array}{l}1.02 \pm 0.14 \\
2.86 \pm 2.86\end{array}$ \\
\hline $\begin{array}{l}\text { Pinitol A serie: } \\
\text { galactopinitol A } \\
\text { ciceritol } \\
\text { trigalactopinitol A }\end{array}$ & $\begin{array}{c}0.17 \pm 0.02 \\
1.57 \pm 0.25 \\
0\end{array}$ & $\begin{array}{c}0.16 \pm 0.02 \\
1.60 \pm 0.05 \\
0\end{array}$ & $\begin{array}{c}0.24 \pm 0.02 \\
3.13 \pm 0.08 \\
12.36 \pm 1.22\end{array}$ & $\begin{array}{c}0.29 \pm 0.02 \\
5.64 \pm 0.67 \\
21.24 \pm 0.06\end{array}$ & $\begin{array}{c}0.24 \pm 0.01 \\
0.41 \pm 0.06 \\
0\end{array}$ & $\begin{array}{l}0.24 \pm 0.07 \\
1.27 \pm 0.18 \\
2.31 \pm 0.32\end{array}$ \\
\hline $\begin{array}{l}\text { Pinitol B serie: } \\
\text { galactopinitol B } \\
\text { digalactopinitol B } \\
\text { trigalactopinitol A }\end{array}$ & $\begin{array}{c}0.13 \pm 0.04 \\
0 \\
0\end{array}$ & $\begin{array}{c}0.11 \pm 0.03 \\
0 \\
0\end{array}$ & $\begin{array}{l}0.01 \pm 0.01 \\
6.66 \pm 0.02 \\
9.22 \pm 1.07\end{array}$ & $\begin{array}{l}0.13 \pm 0.04 \\
1.23 \pm 0.21 \\
8.13 \pm 0.64\end{array}$ & $\begin{array}{c}0.15 \pm 0.01 \\
0\end{array}$ & $\begin{array}{l}0.24 \pm 0.04 \\
0.64 \pm 0.11 \\
0.86 \pm 0.08\end{array}$ \\
\hline $\begin{array}{l}\text { raffinose } \\
\text { stachyose } \\
\text { verbascose }\end{array}$ & $\begin{array}{c}17.75 \pm 0.57 \\
51.54 \pm 1.14 \\
5.35 \pm 1.64\end{array}$ & $\begin{array}{c}5.87 \pm 0.98 \\
25.67 \pm 1.37 \\
16.24 \pm 2.27\end{array}$ & $\begin{array}{c}6.83 \pm 0.89 \\
21.82 \pm 0.57 \\
14.75 \pm 2.57\end{array}$ & $\begin{array}{c}6.75 \pm 0.84 \\
43.17 \pm 2.27 \\
22.98 \pm 1.26\end{array}$ & $\begin{array}{c}17.84 \pm 1.22 \\
55.66 \pm 2.68 \\
6.04 \pm 0.52\end{array}$ & $\begin{array}{l}8.88 \pm 0.83 \\
59.2 \pm 5.49 \\
42.0 \pm 2.44\end{array}$ \\
\hline $\begin{array}{l}\text { Sum of sugars } \\
\text { Sum of RFO } \\
\text { Ratio sucrose to RFO } \\
\text { Sum of galactosyl cyclitols }\end{array}$ & $\begin{array}{l}100 \\
74.6 \\
0.25 \\
3.08\end{array}$ & $\begin{array}{c}73 \\
47.8 \\
0.40 \\
3.11\end{array}$ & $\begin{array}{c}96 \\
43.4 \\
0.36 \\
33.75\end{array}$ & $\begin{array}{c}155 \\
72.9 \\
0.45 \\
41.93\end{array}$ & $\begin{array}{l}104 \\
79.5 \\
0.20 \\
3.38\end{array}$ & $\begin{array}{c}153 \\
110.0 \\
0.25 \\
9.44\end{array}$ \\
\hline
\end{tabular}

to-myo-inositol, galactopinitol A, ciceritol and galactopinitol B. The greatest amount of galactosyl cyclitols appeared in the seeds of Lupinus pilosus and Lupinus palaestinus, 41.9 and $33.75 \mathrm{mg} / \mathrm{g}$ d.m., respectively.

Sucrose appeared in biggest amounts in Lupinus pilosus and Lupinus luteus, 32.65 and $27.9 \mathrm{mg} / \mathrm{g}$ d.m., respective1y. The smallest amounts of sucrose were found in the seeds of Lupinus palaestinus and Lupinus hispanicus.

Monosaccharides appeared in minute amounts in the analysed seeds and were represented by fructose, glucose and galactose. Their amounts ranged from $0.01 \%$ to $0.6 \%$ in dry matter. Also cyclitols, D-pinitol (3-O-methyl D-chiro-inositol), D-chiro-inositol and myo-inositol, appeared in small amounts. These quantities approached the level of monosaccharides and ranged from $0.05 \%$ to $0.7 \%$ in dry matter.

\section{DISCUSSION}

Most species of the Fabaceae have seeds with a high proportion of physical exogenous dormancy caused by the te- sta (outer seed coat), which prevents them from imbibing water even under favourable environmental conditions (Morrison et al. 1998). All legume have the same characteristic type of testa. The seeds dry during their desiccation (with the hilum or pleurogram acting as a hygroscopic valve), and the coat hardens and becomes impermeable as the seeds moisture content falls below of $20 \pm 25 \%$, reaching full impermeability at $10 \pm 15 \%$ (van Staden et al. 1989). The seed coat functions as an important mechanical barrier, however it does not contain any soluble sugars.

In the Mediterranean-type ecosystem the major natural mechanism causing dormancy breakage is the disruption of testas in legume soil seed bank (Auld and O'Connell 1991). The thick seed coat is considered unfavourable in the cultivated varieties.

The oligosaccharides of the raffinose series are the main storage material for the seeds. Their amounts vary from a few percent (peas, beans, some lupin species) to ca. $11 \%$ percent in dry matter (lupin) (Cerning-Beroard and Filiatre 1976). The content of RFO differs according to the species, variety, degree of maturity, way of storage (McCleary and Matheson 1974; Frias et al. 1999), temperature of matura- 
tion (Piotrowicz-Cieślak 2002) and other environmental factors (Trugo et al. 1988).

Galactosyl cyclitols, similarly to RFO, are a vast group occurring in many species (Horbowicz and Obendorf 1994). The seeds of buckwheat, castor-oil plant and lentils are especially rich in galactosyl cyclitols. The seeds of cultivated lupin contain up to $2 \%$ galactosyl cyclitols in dry matter (Piotrowicz-Cieślak et al. 1999). In seeds of yellow lupin of the Juno variety the amount of galactosyl cyclitols was about $1 \%$ d.m. The greatest amount of galactosyl cyclitols was found in L. pilosus and L. palaestinus, 4.1 and $3.3 \%$ d.m., respectively. The amount of galactosyl cyclitols depends on the presence of free cyclitols in the seeds, since they function as substrates for galactosyl cyclitols biosynthesis (Piotrowicz-Cieślak et al. 2004). In the analysed seeds, however, no clear correlation between the presence of galactosyl cyclitols and cyclitols could be found. In mature seeds of L. palaestinus the amount of cyclitols is the lowest among all the analysed seeds, it is $0.5 \mathrm{mg} / \mathrm{g} \mathrm{d.m}$. The ability to link galactose and cyclitols is undoubtedly determined genetically.

A decrease in the share of seed testa in the seeds would cause an increase in the amounts of RFO and galactosyl cyclitols, without any necessity to husk the seeds. The amount of soluble sugars in whole seeds of L. pilosus is lower than $115.8 \mathrm{mg} / \mathrm{g}$ d.m., while in seeds devoid of testas it is $155 \mathrm{mg} / \mathrm{g} \mathrm{d} . \mathrm{m}$. The thin testas cause the seeds to germinate faster, which is quite favourable with respect to the cultivated forms, while not always important with respect to the wild-growing ones. Changing the share of testa in seed tissues from 33.8 to $23 \%$, with unaffected soluble sugar level in the embryo would raise the soluble sugar level in whole seed by nearly $10 \%(8.2 \%)$.

\section{ACKNOWLEDGEMENTS}

This work was financially supported by the State Committee for Scientific Research (KBN) grant number 3 P06A 00523.

\section{LITERATURE CITED}

ALLES M.S., HARTEMINK R., MEYBOOM S., HARRYVAN J.L., VAN LAERE K., NAGENGAR F.M., 1999. Effect of transgalactooligosaccharides on the composition of the human intestinal microfora and on putative risk markers for colon cancer. Am. J. Clin. Nutr. 69: 980-991.

AULD T.D., O'CONNELL M.A. 1991. Predicting patterns of post-fire germination in 35 eastern Australian Fabaceae. Aust. J. Ecol. 16: 53-70.

CERNING-BEROARD J., FILIARTE A. 1976. A comparison of the carbohydrate composition of legume seeds: horse beans, peas, and lupines. Cereal Chem. 53: 968-978.

FRIAS J., BAKHSH A., JONES D.A., ARTHUR A.E., VIDALVALVERDE C., RHODES M.J.C., HEDLEY C.L. 1999. Ge- netic analysis of raffinose oligosaccharides pathway in lentil seeds. J. Exp. Bot. 50 (333): 469-476.

GIBSON G.R., ROBERFROID M.D. 1995. Dietary modulation of the human colonic microbiota: Introducing the concept of prebiotics. J. Nutr. 125: 1401-1412.

GLADSTONES J.S. 1998. Distribution, origin, taxonomy, history and importance. In: Lupins as crop plants: Biology, production and utilization. Eds. J.S. Gladstones, C. Atkins, J. Hamblin. Cab International.

GÓRECKI R.J., PIOTROWICZ-CIEŚLAK A.I., OBENDORF R.L. 1997. Soluble sugars and flatulence-producing oligosaccharides in maturing yellow lupin (Lupinus luteus L.) seeds. Seed Sci. Res. 7: 185-193.

HAMILTON-MILLER J. 2000. Can probiotic products improve health. Clin. Pulse 60: 53-57.

HEYN C.C., HERRNSTADT I. 1977. Seed coat of Old World Lupinus species. Botaniska Notiser 130: 427-435.

HOLDENMANN W. 1984. The lupin - ancient and modern crop plant. TAG: 68: 1-9.

HORBOWICZ M., OBENDORF R.L. 1994. Seed desiccation tolerance and storability: dependence on flatulence-producing oligosaccharides and cyclitols - review and survey. Seed Sci. Res. 4: 385-405.

MCCLEARY B.V., MATHESON N.K. 1974. Alpha-D-galactosidase activity and galactomannan and galactosyl sucrose oligosaccharide in germinating legume seeds. Phytochemistry 13: 1747-1757.

MORRISON D.A., MCCLAY K., PORTER C., RISH S. 1998. The Role of the Lens in Controlling Heat-induced Breakdown of Testa-imposed. Dormancy in Native Australian Legumes. Ann. Bot. 82: 35-40.

PIOTROWICZ-CIEŚLAK A.I., GÓRECKI R.J., ADOMAS B. 1999. The content and composition of soluble carbohydrates in lupin seeds of different species and cultivars. Plant Breeding and Seed Sci. 43 (2): 25-34.

PIOTROWICZ-CIEŚLAK A.I., MICHALCZYK D.J., GÓRECKI R.J. 2004. Flatulence-producing galactosyl cyclitols d-chiroinositol fraction in maturing yellow lupin seeds. $4^{\text {th }}$ International Workshop on Antinutritional Factors in Legume Seed and Oilseeds. EAAP Publication 110: 67-70

PIOTROWICZ-CIEŚLAK A.I. 2002. Wpływ temperatury na zawartość cukrów rozpuszczalnych i jakość fizjologiczną nasion łubinu żółtego. Zeszyty Problemowe Postępów Nauk Rolniczych 481: 205-210 (in Polish).

PIOTROWICZ-CIEŚLAK A.I., GRACIA-LOPEZ P.M., GULEWICZ K. 2003. Cyclitols, galactosyl cyclitols and raffinose family oligosaccharides in Mexican wild lupin seeds. Acta Soc. Bot. Pol. 72 (2): 109-114.

TOMOMATSU H. 1994. Health effects of oligosaccharides. Food Technol. 48: 61-65.

TRUGO L.C., ALMEIDA D.C.F., GROSS R. 1988. Oligosaccharide contents in the seeds of cultivated lupins. J. Sci. Food Agricult. 45: 21-24.

TURNER B.L. 1995 A new species of Lupinus (Fabaceae) from Oaxaca, Mexico: a shrub or tree mostly three to eight meters high. Phytologia 79: 102-107.

VAN STADEN J., MANNING J.C., KELLY K.M. 1989. Legume seeds-the structure: function equation. In: Advances in legume biology. Stirton C.H., Zarucchi J.L. (eds), St Louis: Missouri Botanical Garden. 